\title{
Literary Features in the First Cycle of Speeches in LXX Job ${ }^{1}$
}

\author{
Marieke Dhont
}

\begin{abstract}
The LXX is to be regarded both as a translation and as a literary creation in its own right. When encountering literary features in the Greek text, the question arises whether these features have their basis in the Hebrew text or whether they are introduced autonomously by the translator-especially in the case of a "free" translation such as LXX Job, which is known to be a Atticized and stylized text. This article looks at the use of literary features in LXX Job 3-14, especially related to word-order (symmetry and chiasmus) and lexical repetitions (primarily anaphora and epiphora). As such, some new insights are gained in the aspects of "freedom" of the Greek translation of the book of Job.
\end{abstract}

\section{INTRODUCTION}

Scholarly attention to the presence of literary features in the LXX has increased in the past decades. ${ }^{2}$ In this respect, we find ourselves at the

1. Participation in this conference was made possible through funding obtained from the FWO Vlaanderen and KU Leuven OT 09/001.

2. To name but a few: James K. Aitken, "Rhetoric and Poetry in Greek Ecclesiastes," BIOSCS 38 (2005): 55-78; Eberhard Bons and Thomas Kraus, eds., Et sapienter et eloquenter: Studies on Rhetorical and Stylistic Features of the Septuagint, FRLANT 241 (Göttingen: Vandenhoeck \& Ruprecht, 2011); Deborah Gera, "Translating Hebrew Poetry into Greek Poetry: The Case of Exodus 15," BIOSCS 40 (2007): 107-20; John Gammie, "The Septuagint of Job: Its Poetic Style and Relationship to the Septuagint of Proverbs," CBQ 49 (1987): 13-31; Takamitsu Muraoka, "Literary Device in the Septuagint," Text 8 (1973): 20-30; Gerhard Tauberschmidt, Secondary Parallelism: A Study of Translation Technique in LXX Proverbs, AcBib 15 (Atlanta: Society of Biblical Literature, 2004); Theo van der Louw, Transformations in the Septuagint: Towards an 
crossroads of considering the LXX as a translation and as a literary creation in its own right. After all, the presence of literary features in the LXX implies that the Greek translators might have rendered a certain feature of the Hebrew text on the one hand or that they might have added features to the Greek text autonomously on the other. Both aspects are part of the so-called "translation technique"3 of a LXX book.

Taking into consideration the assumption that each LXX book has been translated by a different translator and has therefore its own characteristic translation "technique(s)," this article focuses on the book of Job. It is one of the most poetic biblical books and as such very rich in literary features. ${ }^{5}$ Moreover,

Interaction of Septuagint Studies and Translation Studies, CBET 47 (Leuven: Peeters, 2007); Mirjam van der Vorm-Croughs, The Old Greek of Isaiah: An Analysis of Its Pluses and Minuses, SCS 61 (Atlanta: Society of Biblical Literature, 2014), esp 139-204.

3. A characterization of the LXX translation technique can be defined as a description of the working habits and abilities of the translator of a LXX book; see Anneli Aejmelaeus, "Characterizing Criteria for the Characterization of the Septuagint Translator: Experimenting on the Greek Psalter," in The Old Greek Psalter: Studies in Honour of Albert Pietersma, ed. Robert V. J. Hiebert, Claude Cox, and Peter Gentry, JSOTSup 332 (Sheffield: Sheffield Academic Press, 2001), 54-73 (56). See also Timothy McLay, The Use of the Septuagint in New Testament Research (Grand Rapids: Eerdmans, 2003), 39.

4. Aejmelaeus, "Characterizing Criteria," 55; Martin Rösel, "Translators as Interpreters: Scriptural Interpretation in the Septuagint," in A Companion to Biblical Interpretation in Early Judaism, ed. Matthias Henze (Grand Rapids: Eerdmans, 2011), 64-91 (69). This statement should, however, be nuanced. Firstly, some scholars observed that one and the same biblical book can witness a wide range of translation techniques, indicating that more than one translator might have worked on the translation. See, e.g., Natalio Fernández Marcos, The Septuagint in Context: Introduction to the Greek Version of the Bible, trans. Wilfred G. Watson (Leiden: Brill, 2000), 22-23; Gilles Dorival, Marguerite Harl, and Olivier Munnich, La bible grecque des Septante: Du judaïsme hellénistique au christianisme ancien, Initiations au christianisme ancien (Paris: Cerf, 1988), 108. Secondly, some scholars argue that the translations of certain individual books reveal a very similar translation technique, concluding that they were probably the work of the same translator. For instance, one translator is sometimes believed to be responsible for both Qohelet and Canticum; see, e.g., Jennifer M. Dines, The Septuagint. Understanding the Bible and Its World (London: T\&T Clark, 2004), 20. Job and Proverbs have sometimes been ascribed to the same translator as well; see, e.g., Gammie, "Septuagint of Job," 14-17; Jean-Daniel Kaestli, "La formation et la structure du canon biblique: Que peut apporter l'étude de la Septante," in The Canon of Scriptures in Jewish and Christian Tradition. Le canon d'Écritures dans les traditions juive et chrétienne, ed. Philip S. Alexander and Jean-Daniel Kaestli, Publications de l'Institut romand des sciences bibliques 4 (Lausanne: Zèbre, 2007), 99-113 (106).

5. See, e.g., Robert Alter, The Art of Biblical Poetry (New York: Basic Books, 1985), 76; Edouard Dhorme, A Commentary on the Book of Job, trans. Harold Knight (London: Nelson, 1967 [first published as Le livre de Job, 1926]), clxxv-clxxix; Robert 
the Greek translation is notorious for its qualitative and quantitative deviations from the MT, ${ }^{6}$ although scholarship tends to assume the translator is responsible for most deviations. ${ }^{7}$ It is a very "free" translation, ${ }^{8}$ and scholars typically

Gordis, The Book of God and Man: A Study of Job (Chicago: University of Chicago Press, 1965), 157-68; David Clines, "On the Poetic Achievement of the Book of Job," in Palabra, Prodigio, Poesía, in Memoriam P. Luis Alonso Schökel, ed. Vicente. Collado Bertomeu, AnBib 151 (Rome: Editrice Pontificio Istituto Biblico, 2003), 243-52; Edward L. Greenstein, "Difficulty' in the Poetry of Job," Online Proceedings of the Fifteenth World Congress of Jewish Studies (August 2-6, 2009) (2010), 1-15; Gregory W. Parsons, "Literary Features of the Book of Job," BSac 138 (1981): 213-29.

6. The approximate percentage of the number of missing stichoi in the LXX compared to the MT in relation to the poetic composition of the book have been calculated: 4 percent in the first cycle of speeches (Job 3-14), 16 percent in the second cycle (Job 15-21), 25 percent in the third cycle (Job 22-31), 35 percent in the speech of Elihu (Job 32-37), and 16 percent in the speeches of Yahweh (Job 38-42:26); see Samuel R. Driver and George B. Gray, A Critical and Exegetical Commentary on the Book of Job together with a New Translation, ICC (Edinburgh: T\&T Clark, 1964), lxxv.

7. Robert Althann, "Reflections on the Text of the Book of Job," in Sôfer Mahîr. Essays in Honour of A. Schenker Offered by the Editors of Biblia Hebraica Quita, ed. Yohanan Goldman, Arie van der Kooij, and Richard Weis, VTSup 110 (Leiden: Brill, 2006), 7-14; Moses Buttenwieser, The Book of Job (New York: McMillan, 1922), viiiix; Claude Cox, "Methodological Issues in the Exegesis of LXX Job," in VI Congress of the International Organization for Septuagint and Cognate Studies. Jerusalem, 1986, ed. Claude Cox, SCS 23 (Atlanta: Scholars Press, 1986), 79-89, 80; Hans Debel, "Greek 'Variant Literary Editions' to the Hebrew Bible?,' JSJ 41 (2010): 161-90 (174-75), and 189-90; August Dillmann, "Textkritisches zum Buche Ijob," Sitzungsberichte der Königlichen Preussischen Akademie der Wissenschaften zu Berlin 53 (1890): 1345-73; Driver and Gray, Book of Job, lxxiv-lxxvi; Natalio Fernández Marcos, "The Septuagint Reading of the Book of Job," in The Book of Job, ed. Willem A.M. Beuken, BETL 114 (Leuven: Peeters, 1994), 251-66 (252); Donald H. Gard, The Exegetical Method of the Greek Translator of the Book of Job, SBLMS 8 (Philadelphia: Society of Biblical Literature, 1952), 93; Gilles Gerleman, Studies in the Septuagint I: The Book of Job (Lund: Gleerup, 1946), 23; John Gray, "The Massoretic Text of the Book of Job, the Targum and the Septuagint Version in Light of the Qumran Targum (11QtargJob)," ZAW 86 (1974): 331-50 (339-45); Homer Heater, A Septuagint Translation Technique in the Book of Job, CBQMS 11 (Washington: Catholic Biblical Association of America, 1982), 5; Karl V. Kutz, "Characterization in the Old Greek of Job," in Seeking out the Wisdom of the Ancients: Essays Offered to Honor M. Fox on the Occasion of His Sixty-Fifth Birthday, ed. Kevin G. Friebel, Dennis R. Magary, and Ronald L. Troxel (Winona Lake, IN: Eisenbrauns, 2005), 345-55, 345-46; Emanuel Tov, Textual Criticism of the Hebrew Bible, 3rd ed. (Minneapolis: Fortress, 2011), 138.

8. Some of the oldest sources include Zacharias Frankel, Vorstudien zu der Septuaginta (Leipzig: Vogel, 1841), 239; Henry St. J. Thackeray, Introduction, Orthography and Accidence, vol. 1 of A Grammar of the Old Testament in Greek according to the Septuagint (Cambridge: University Press, 1909), 13. In the past decades, 
characterize the Greek of LXX Job as both highly Atticized and stylized. ${ }^{9}$ The particular aspects of the translator's "freedom" have yet to be studied in an indepth and systematic manner. In this paper, I will focus on one aspect of that "freedom" pertaining to the stylization, namely the use of literary features.

Poetics are manifold and related to the linguistic structure of a language. Parallelism, defined as the dynamic correspondence of one line or verse with another on a phonological, morphological, grammatical, syntactical and/or semantic level, ${ }^{10}$ is one of the main constituents of Hebrew poetry. Greek poetry, however, is structurally defined primarily on the basis of meter. As such, we encounter a difference in the formal characteristics of both languages. One is confronted with these differences when translating, such as in the case of the Greek translation of Hebrew book of Job, especially when one claims a certain translational "freedom." Now what does this freedom mean with regard to the poetic character of a book? Some scholars have addressed this issue in the past. S. Driver and G. Gray, for example, noted that the LXX translator of Job often destroys the poetical structure of the Hebrew text by depriving one parallel line of its fellow. ${ }^{11}$ The majority of parallel lines, however, are in fact rendered. Hence, we are invited to look at how the translator's "freedom" works when he does render the parallelisms. R. Althann did so in an article on Job 3, a chapter with basically no omitted lines. He stated that "the verses of Job $3 \ldots$ show that while the MT presents the characteristics of Hebrew poetry including parallelism, chiasmus, merismus, the OG is prosaic." ${ }^{\prime 2}$ This statement raises a number of issues pertinent to the discussion:

a large number of authors have made similar statements. To name a few: Johann Cook, "The Septuagint of Job," in Law, Prophets, and Wisdom: On the Provenance of Translators and Their Books in the Septuagint Version, ed. Johann Cook and Arie van der Kooij, CBET 68 (Leuven: Peeters, 2012), 175-219 (177); Dhorme, Job, cxcvi-cxcix; Driver and Gray, Job, lxxvi; Gerleman, Studies in the Septuagint I, 5; Max L. Margolis, The Story of Bible Translations (Philadelphia: Jewish Publication Society of America, 1917), 36; Kutz, "Characterization," 345; Harry M. Orlinsky, "Studies in the Septuagint of the Book of Job, Chapter II: The Character of the Septuagint Translation of the Book of Job," HUCA 29 (1958): 229-71; Emanuel Tov, The Text-Critical Use of the Septuagint in Biblical Research, 2nd ed., JBS 8 (Jerusalem: Simor, 1997), 18.

9. See, e.g., Claude Cox, "The Historical, Social and Literary Context of Old Greek Job," in XII Congress of the International Organization for Septuagint and Cognate Studies. Leiden, 2004, ed. Melvin K. H. Peters, SCS 54 (Atlanta: Society of Biblical Literature, 2006), 105-16 (111); Gammie, "Septuagint of Job," 13-31; Gerleman, Book of Job, 14; Fernández Marcos, "Septuagint Reading," 256.

10. Adele Berlin, The Dynamics of Biblical Parallelism, rev. and exp. ed., Biblical Resource Series (Grand Rapids: Eerdmans, 2008), 8; 25.

11. Driver and Gray, Job, lxxv.

12. Robert Althann, "Job 3 in the Masoretic Text and the Septuagint," Orientalia 78 (2009): 337-57 (355). 
(1) Defining a translation as poetry according to the rules of the source language seems to be a pitfall, since each language is structured differently.

(2) Hence, if we define Greek poetry according to the rules of Greek language, namely in terms of meter and observe that no meter can be found in the LXX translation, ${ }^{13}$ then evidently, the Greek is prosaic.

(3) Yet, I do not think one should characterize the LXX in terms of poetry or prose. Rather, as a translation of Hebrew poetry, it will contain literary features found in the source text, but as a literary composition in its own right, it can also contain autonomously used elements that lend the text a certain ornatus, especially since features such as chiasmus are not only characteristic of Hebrew poetry but also of Greek poetry.

Against this background, I want to look at the use of literary features in LXX Job. Given the limited framework of this contribution, I focus on specific types of repetition within parallel lines ${ }^{14}$ on the microlevel, that is, within units of consecutive verses, ${ }^{15}$ that can be seen as literary features, in particular wordorder (symmetry and chiasmus) and lexical patterns (especially anaphora and epiphora). ${ }^{16}$ I limit my corpus to Job 3-14, the first cycle of speeches and those chapters with the least number of untranslated lines. ${ }^{17}$ In the presentation of the examples, I will not discuss translational aspects that have no bearing on the literary features found in the (Greek and/or Hebrew) text.

13. See Cook, "Septuagint of Job," 178.

14. Here considered to be those lines that are related on the basis of a semantic correpondence.

15. It is not unlikely that repetition in larger units of verses also constitutes a literary figure, but because of the limited scope of this paper and because of the aim to take features as unambiguous as possible as point of departure, I limit this research to literary figures occurring in consecutive verses. A verse can consist of several cola; hence, repetition within nonconsecutive cola of consecutive verses are taken into consideration.

16. There are many more patterns of repetition, such as anadiplosis, complexio, parenthesis, and so on, but it would lead us too far to discuss all literary features. Anaphora and epiphora are said to be the most common feature in biblical rhetoric (see Roland Meynet, Rhetorical Analysis: An Introduction to Biblical Rhetoric, JSOTSup 256 [Sheffield: Sheffield Academic Press, 1998], 136) but are also "idiomatic" or "autonomous" Greek features.

17. The editions used are, for the Greek, Joseph Ziegler, ed., Iob, Septuaginta Vetus Testamentum Graecum 11.4 (Göttingen: Vandenhoeck \& Ruprecht, 1982) (English translation: NETS), and for the Hebrew, Karl Elliger and Wilhelm Rudolph, eds. Biblia Hebraica Stuttgartensia (Stuttgart: Deutsche Bibelgesellschaft, 1990) (English translation: NRSV). I sometimes propose an alteration in the translations, indicated with square brackets. As to reference works, HR, TLG, LSJ, HALOT, and Accordance have been used. 


\section{A "Literal” Mode of TransLating}

Even though LXX Job is a "free" translation, the translator frequently translates in a "literal mode." 18 The structure of both languages allows patterns of wordorder such as a symmetry $\left(\mathrm{AB} / \mathrm{A}^{\prime} \mathrm{B}^{\prime}\right)$ or a chiasmus $\left(\mathrm{AB} / \mathrm{B}^{\prime} \mathrm{A}^{\prime}\right)^{19}$ to be rendered rather easily.

\subsection{SYMMETRY}

I first present the text of Job 3:1 and 4:9.

Job 3:1

אחרי כן פתח איוב את פיהו ויקלל את יומו

After this Job opened his mouth and cursed the day of his birth [literally: his day].

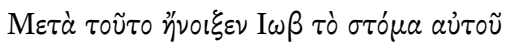

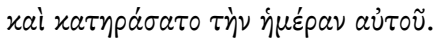

After this, Job opened his mouth

And cursed his day.

Job 4:9

מנשמת אלוה יאבדו ומרוח אפו יכלו

By the breath of God they perish, and by the blast of his anger they are consumed.

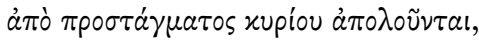

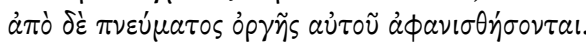

By the command of the Lord they will perish, and by the breath of his anger they will disappear.

In both examples, each element in the Hebrew text has a corresponding equivalent in the Greek translation that reflects the same meaning. The word order of the translation follows that of the Hebrew. ${ }^{20}$ As such, the symmetrical

18. See, e.g., Althann, "Reflections," 7; Gard, Exegetical Method, 3; Fernández Marcos, "Septuagint Reading," 254; Kutz, "Characterization," 345-55; Harry M. Orlinsky, "Studies in the Septuagint of the Book of Job, Chapter III: On the Matter of Anthropomorphisms, Anthropopathisms, and Euphemisms," HUCA 30 (1959): 153-67; Harry M. Orlinsky, "Studies in the Septuagint of the Book of Job, Chapter III (continued)," HUCA 32 (1961): 239-68.

19. This includes partially parallel or partially chiastic structures, such as $\mathrm{ABC} / \mathrm{B}^{\prime} \mathrm{C}^{\prime}$, $\mathrm{ABC} / \mathrm{A}^{\prime} \mathrm{C}^{\prime}, \mathrm{ABC} / \mathrm{C}^{\prime} \mathrm{B}$ ', $\mathrm{ABC} / \mathrm{AC}^{\prime} \mathrm{B}^{\prime}$, and so on.

20. I do not go into the translator's use of particles. Although they are an important aspect of LXX Job, the translator's choice for xai or $\delta \varepsilon$ to render the Hebrew copula 1 
word order of the cola in 3:1 as well as in 4:9 is retained. Note also the fact that in 4:9 both cola in the Hebrew text start with the preposition מן, an anaphora which is retained in the Greek translation by using ả ó $^{\prime}$ twice.

\subsection{CHIASMUS}

The first example of a "literal" rendering of a chiasmus is 3:17.

Job 3:17

שם רשעים חדלו רגז ושם ינוחו יגיעי כח

There the wicked cease from troubling, and there the weary [of strength] are at rest.

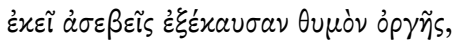

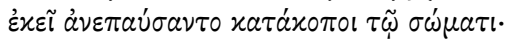
There the impious have kindled a terrible wrath; there the very weary have found rest for the body [my suggestion: there the weary of body have found rest $].^{21}$

In this verse, the Hebrew contains two features: an anaphora of שם, as well as a

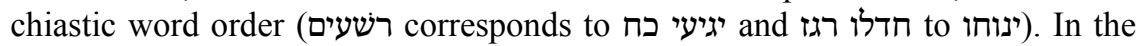
Greek, both elements have been retained.

Yet, even in the process of translating "literally," there are indications that the translator of LXX Job did have an (conscious or subconscious) eye for detail. I present the following example.

Job $7: 14$

וחתתני בחלמות ומחזינות תבעתני

Then you scare me with dreams and terrify me with visions.

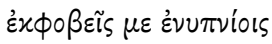

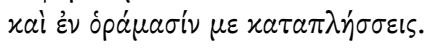

You scare me with dreams

and terrify me with visions.

does not have an effect on the word order in the examples given in this paper. A good study of the use of particles in LXX Job is offered by Claude Cox, "Tying It All Together: The Use of Particles in Old Greek Job," BIOSCS 38 (2005): 41-54.

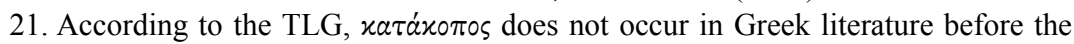
LXX. Hence, we cannot prove that this adjective can have a complement in the dative.

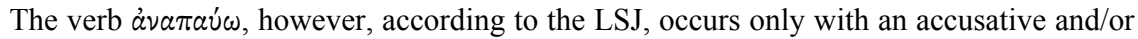
a genitive, not with a dative. The dative is thus, in my opinion, more likely to belong to

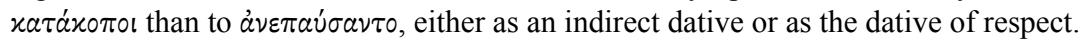


The Greek translation follows the Hebrew closely. The word order is retained, but a notable aspect of the translation pertains to the variation in the position of the personal pronoun indicating the object. In Hebrew, the direct object is indicated by a suffix. In Greek, however, verb and object are two distinct words, which can be put in different order (verb-object or object-verb). ${ }^{22}$ The translator takes advantage of this possibility to add variation. When we look at all instances in chapters 3-14 in which the Greek has a similar construction, that is, a parallel construction with two verbs with an identical object expressed by using a personal pronoun, we observe that the translator varies the position of the pronoun. In eight cases, the personal pronoun stands behind the verb in both cola. ${ }^{23}$ In two cases, the personal pronoun stands before the verb. ${ }^{24}$ The variation we encounter in 7:14 occurs five more times in LXX Job 3-14. ${ }^{25}$ In some cases,

22. In noninterrogative sentences with a verb and an object expressed by a pronoun, the most common word order is object-verb (I include the genitive or dative with verbs that do not have an accusative as their complement and/or take a genitive or dative as their indirect object); see the study of Kenneth J. Dover, Greek Word Order (Cambridge: Cambridge University Press, 1960), in particular pages 26-28.

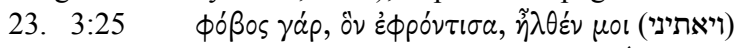

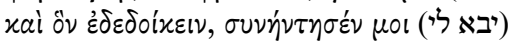

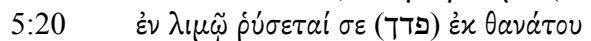

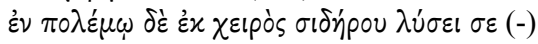

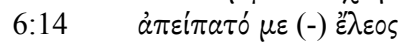

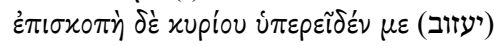

6:23 (ומלטוני)

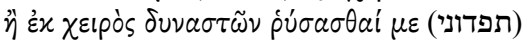

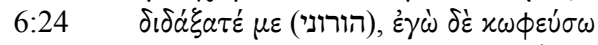

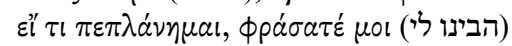

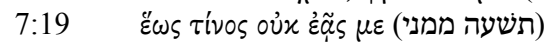

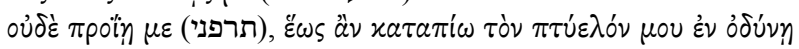

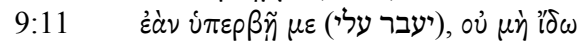

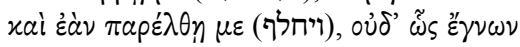

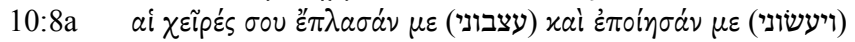

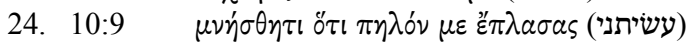

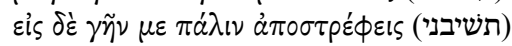

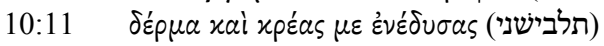

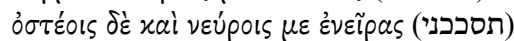

25. 6:9 a

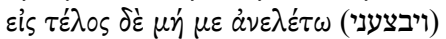

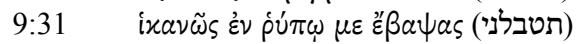

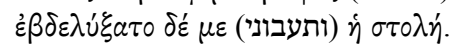

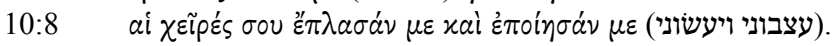

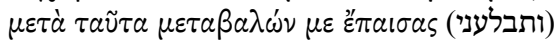

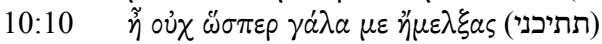

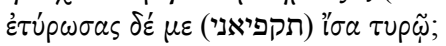


this alternation might add to the chiastic structure, as is the case in this example: $\dot{\varepsilon} \varkappa \phi \circ \beta \varepsilon \tilde{\iota} \varsigma \mu \varepsilon$ versus $\mu \varepsilon \varkappa \alpha \tau \alpha \pi \lambda \dot{\eta} \sigma \sigma \varepsilon \mid{ }^{26}{ }^{26}$

In cases like the ones presented above, the question posed by R. Gauthier, "whether poetic devices such as parallelism are intentional in the translated Greek of [a LXX book] is questionable," ${ }^{27}$ cannot be answered. There are, however, examples in LXX Job which indicate otherwise - namely, those in which the translator departs from a "literal" mode and demonstrates a certain "freedom" with respect to the use of literary features.

\section{3. "FreE" Modes of TRANSLATING}

\subsection{ADDING REPETITIONS}

When looking at the "free" renderings in chapters 3-14, our translator often seems to make the elements of a symmetry or a chiasmus correspond more strictly. In these cases, a word-order repetition or inversion in the Greek text has its basis in the Hebrew text, but certain deviations can be explained on the basis of the literary context.

In Job 7:4, for example, a clear eye for stylistic details can be noticed. A rather strict symmetrical parallelism in word order was added in the translation of a verse which was only semantically parallel in Hebrew. ${ }^{28}$

Job 7:4

אם שכבתי ואמרתי מתי אקום ומדד ערב ושבעתי נדדים עדי נשף

When I lie down I say, 'When shall I rise?'

But the night is long,

and I am full of tossing until dawn.

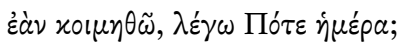

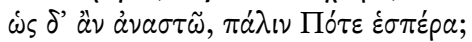

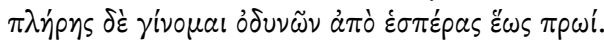

If I lie down, I say, 'when will it be day?'

26. See also 10:10.

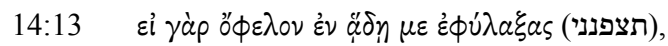

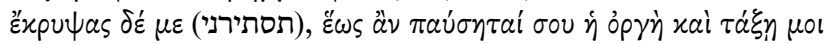

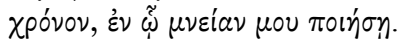

27. Randall X. Gauthier, "Examining the 'Pluses' in the Greek Psalter: A Study of the Septuagint Translation qua Communication," in Septuagint and Reception: Essays Prepared for the Association for the Study of the Septuagint in South Africa, ed. Johann Cook, VTSup 127 (Leiden: Brill, 2009), 45-76 (61 n. 58).

28. Commentators sometimes suggest conjectural emendation of the MT on the basis of the LXX; for an overview, see David J. Clines, Job 1-20, WBC 17 (Texas: Word, 1989), 198. 
But when I get up, again I say, 'when will it be evening?'

And I am full of pain from evening until morning.

Often the translator will also employ other elements of repetition within parallel lines, such as anaphora or epiphora. ${ }^{29}$ The first example is Job 3:12.

\section{Job 3:12}

מדוע קדמוני ברכים ומה שדים כי אינק

Why were there knees to receive me, or breasts for me to suck?

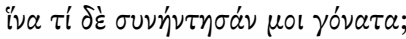

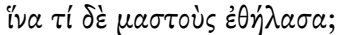

Why then did the knees meet me?

Why then did I such breasts?

In the Hebrew text, both cola start with an interrogative, first מדוע, then מה. The translator, however, opts to use the same interrogative particle twice, introducing both questions with iva $\tau i \delta^{\prime} \varepsilon^{30}$ introducing an anaphora. Moreover, the Hebrew text is partially chiastically structured (ABC/A'C'B'), with ברכים corresponding to כי אינק to כדמוני שדים This structure is rendered identically in Greek, but

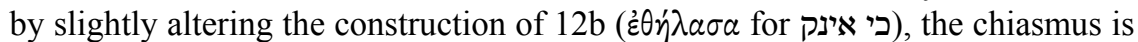
made more strictly chiastic. As such, the rendering shows less variation than the Hebrew text does.

A comparable example can be found in Job 9:20.

Job 9:20

\section{אם אצדק פי ירשיעני תם אני ויעקשני}

Though I am innocent, my own mouth would condemn me;

though I am blameless, he would prove me perverse.

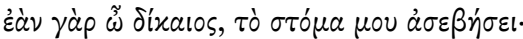

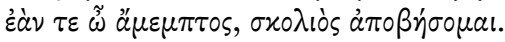

For if I should be right, my mouth will be impious,

And if I should be blameless, I will turn out perverse.

29. In order to demonstrate that the occurrence of such a feature is not merely due to the relationship between two different Hebrew words being rendered by one and the same Greek word in other instances in LXX Job and the lexical repetition hence introduced "coincidentally," one needs to pay attention to the translator's word choices - and hence use concordances intensively. I will do so mostly in the footnotes.

30. The Greek interrogative iva $\tau i$ occurs more often in LXX Job (namely, in 3:20; 10:18; 30:2), but each time as a translation of למה. The Hebrew interrogative מדוע occurs

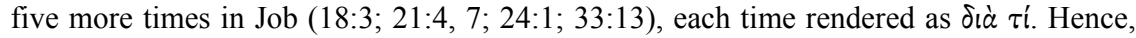
the double use of 'iva $\tau$ ' here might be considered indicative. 
The LXX has a strict structural repetition: $\dot{\varepsilon} \alpha \dot{\alpha} \nu+\varepsilon i \mu \dot{u}^{\prime}$ in the subjunctive mood + adjective. The Hebrew is less "strict." First, the particle תם is gapped in the second colon. Second, the first colon has a verb (אצדק) and the second a nominal clause (תם אני). ${ }^{31}$

Aside from using anaphora, the translator of LXX Job also sometimes employs an epiphora. Job 4:7 presents us with an example.

Job $4: 7$

זכר נא מי הוא נקי אבד ואיפה ישרים נכחדו

Think now, who that was innocent ever perished?

Or where were the upright cut off?

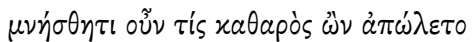

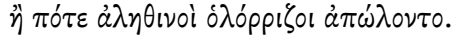

Think now, who, being pure, perished,

or when did the true perish root and all?

The cola in Hebrew end with two different words, כחד מבד and. In LXX Job, $\dot{a} \pi \dot{\delta} \lambda \lambda u \mu l$ is more often used to render כחד מבד but differently. ${ }^{33}$ Hence, the choice to use $a \dot{a} \delta^{\prime} \lambda \lambda u \mu l$ twice in this verse has been influenced by the literary context: the translator introduces an epiphora.

Another illustration of the same "technique" can be found in Job 5:6-7.

Job 5:6-7

כי לא יצא מעפר און ומאדמה לא יצמח עמל

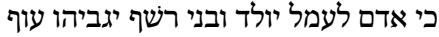

For misery does not come from the earth, nor does trouble sprout from the ground; but human beings are born to trouble just as sparks fly upward.

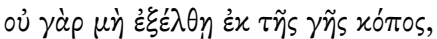

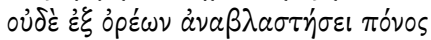

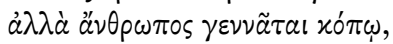

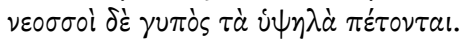

For hardship shall not come from the earth, nor will trouble sprout from mountains,

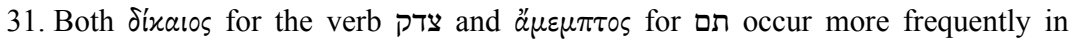
LXX Job (respectively $9 x$ and $2 x$ or possibly $3 x$ or even $4 x$ ).

32. More specifically, in eleven out of fifteen cases; see Job $3: 3 ; 4: 7,9,20 ; 6: 18$; $8: 13 ; 12: 23 ; 18: 17 ; 20: 7 ; 29: 13 ; 31: 19$. See also ó $\lambda \lambda \nu \mu \iota$ in $4: 11$. Twice אבד occurs in a line that is in the LXX part of the so-called asterisked material.

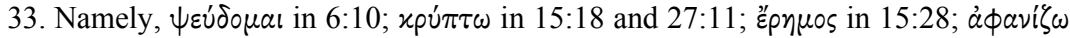
in 22:20. 
but a human being is born to hardship,

whereas the vulture's young soar on high.

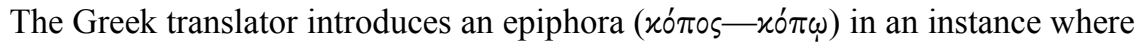
the Hebrew text does not have a lexical repetition. The Hebrew does present its own features, which were not retained in the translation. First, עמל is repeated, occurring at the end of $6 \mathrm{~b}$ and mid-colon in $7 \mathrm{a}$. The Greek translator renders the first instance as $\pi o^{\prime} v o \varsigma$ and the second as $x o ́ \pi \omega .{ }^{34}$ Second, the Hebrew features an anaphora of , which is eliminated in the translation. ${ }^{35}$

\subsection{ELIMINATING REPETITIONS}

When comparing Job 3:17 to 5:6-7, both discussed supra, one can observe a different translation technique. In 3:17, the translator renders the repetition of שם by ह̇ंxĩ. In 5:6-7, however, the repetition is avoided. Another example of this process of elimination can be found in Job 8:3.

Job 8:3

האל יעות משפט ואם שדי יעות צדק

Does God pervert justice?

Or does the Almighty pervert the right?

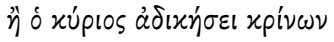

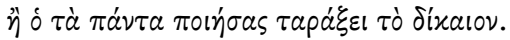

Will the Lord act unjustly when he judges,

or will the maker of all things pervert what is right?

In this verse, the Hebrew employs the exact same form of עות twice, while the Greek translator opts for two different renderings ( $\dot{\alpha} \delta(x \dot{\eta} \sigma \varepsilon l$ and $\tau \alpha \rho a \dot{\xi} \xi \varepsilon l)$. Job 8:3 is the only instance in LXX Job in which עות is rendered as $\dot{\alpha} \delta\llcorner x \varepsilon \dot{\varepsilon} \omega$; in the other three instances, ${ }^{36}$ the rendering is consistent. We may not disregard the possibility that this "deviation" might be due to the semantic requirements of the context. Nonetheless, it might have been a matter of avoiding repetition, as in

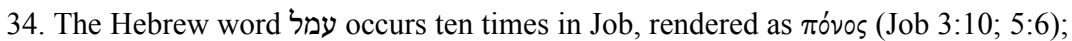
$\pi$ ixpía (Job 3:20); ódúv (Job 4:8; 7:3; 15:35; though possibly also in 3:20 if one accepts a transposition of elements in the LXX); xó (?) (Job 20:22).

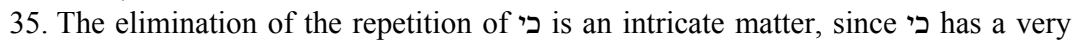
wide semantic range in the Hebrew, which could be reflected by a wide range of possible renderings in the LXX, especially since the Greek language has more particles to express relations between lines.

36. Job 8:3b; 19:6; 34:12. 
Job 5:6-7. ${ }^{37}$ Moreover, the construction of both cola in Hebrew is identical (subject-verb-object), whereas the Greek renders the noun משפט as a participle, xpivav. This example indicates that the LXX's tendency to avoid repetition present in the Hebrew text can result in a translation which is less strictly parallel in form.

A similar example is found in 9:19, in which the translation does not render the anaphora of the Hebrew (אם ל-).

Job 9:19

אם לכח אמיץ הנה ואם למשפט מי יועידני

If it is a contest of strength, he is the strong one!

If it is a matter of justice, who can summon him?

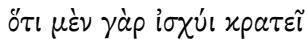

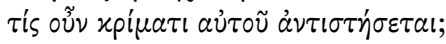

Because, for one thing, he prevails by force;

who then can withstand his judgment?

It is striking that lexical repetitions occur regularly in both the Hebrew text as well as in the Greek translation but that cases of repetition in the Hebrew text are often eliminated in the translation. ${ }^{38}$ So as to give a general idea, if we do not take particles, prepositions, proper names, ${ }^{39}$ or paronomastic constructions into account and disregard whether or not the repetition occurs within the context of literary features such anaphora, but merely focus on repetition of the same word, ${ }^{40}$ Job 3-14 displays the following tendencies. There are sixteen instances

37. See Gordis, Job, 508-551; Clines, Job 1-20, 198.

38. Robert Gordis already noted that the LXX tends to eliminate repetition found in the Hebrew text. He presented an incomplete list of forty-three rather random instances of repetition in the Hebrew text; see Robert Gordis, The Book of Job. Commentary, New Translation and Special Studies, Moreshet 2 (New York: Jewish Theological Seminary of America, 1978), 509.

39. Except for the name attributed to God, since the translator actually had a choice, for example, xúpı

40. With this specification, I carefully touch upon the issue of the polyptoton. So as to avoid terminological confusion, especially since a polyptoton is generally defined differently in inflected languages (Greek) than in noninflected languages (Hebrew) and since Greek is more capable of forming composita than Hebrew, I will refrain from including words that are derived from the same root (e.g., ומשגה שגו in MT Job 12:16 and

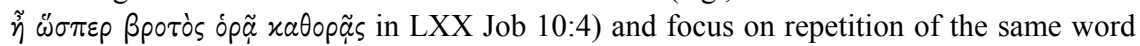
albeit possibly in another form. Nonetheless, I am of the opinion that if one attempts at a systematic study of literary features in the LXX, this type of repetition should also be included, as I do in my doctoral dissertation. The same thing goes for repetition of particles and pronouns. 
in which a repetition in the Hebrew text is rendered in Greek ${ }^{41}$ seventeen instances in which the Greek eliminates a repetition present in the Hebrew text, ${ }^{42}$ and nineteen instances in which the Greek adds a repetition which has no direct basis in the Hebrew text. ${ }^{43}$

The LXX's tendency to eliminate repetition does not only occur in cases of lexical repetition. The following example of Job 6:4 demonstrates how the parallelism of the first and the third cola in the Hebrew text is eliminated in the translation without attention to ornatus of the Greek. E. Dhorme, as one of the very few commentators paying attention to this deviation, noted that it is difficult to understand where ö $\tau \alpha \nu ~ a ̈ p \xi \omega \mu a ı ~ \lambda a \lambda \varepsilon \tilde{\nu}$ for אלוה בעותי comes from. ${ }^{44}$ There does not seem to be any sign of ornatus in the Greek text.

Job 6:4

כי חצי שדי עמדי אשר חמתם שתה רוחי בעותי אלוה יערכוני

For the arrows of the Almighty are in me; my spirit drinks their poison;

the terrors of God are arrayed against me.

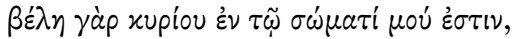

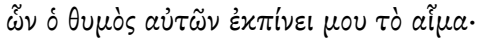

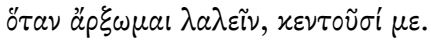

For the arrows of the Lord are in my body, their wrath drinks my blood.

When I begin to speak, they pierce me.

\subsection{PossiBle COMPENSATION?}

Sometimes, in those instances in which literary features seem to get lost in translation, other literary features can be used. One can speculate that this is a way of "compensating" on behalf of the translator. An example can be found in Job 3:24-25.

Job 3:24-25

כי לפני לחמי אנחתי תבא ויתכו כמים שאגתי

כי פחד פחדתי ויאתיני ואשר יגרתי כיותי יבא לי שגי

41. Job $3: 2-3,3-4,4-5,6-7,17 ; 5: 23-24,24-25 ; 6: 8,11-12 ; 9: 9-10 ; 10: 1,8-9$, $21-22 ; 11: 5-7 ; 12: 12-13,24-25$.

42. Job $3: 25-26 ; 5: 6-7,15-16,23 ; 6: 15,23,25-26 ; 8: 3 ; 9: 20-21 ; 10: 4-5,5,7-8$, $19,20,22 ; 13: 7 ; 14: 5-6$.

43. Job $3: 8,9,17,24-25,25-26 ; 4: 7,13 ; 5: 2-3,6-7,8,23-24 ; 6: 17-18,25-26$; $10: 8-9 ; 12: 12 ; 13: 6,17,22 ; 14: 3$.

44. Dhorme, Job, 76. Clines, for example, does not mention anything about this deviation. 
For my sighing comes like my bread, and my groanings are poured out like water. Truly the thing that I fear comes upon me, and what I dread befalls me.

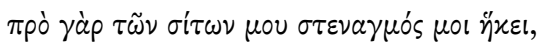

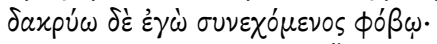

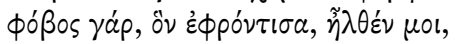

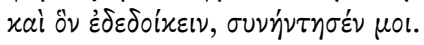

For sighing comes before my food, and I cry, gripped by fear.

For fear, about which I worried, came to me, and that which I was scared about, befell me.

The Greek translation demonstrates quite some "artistic license" with regard to the rendering and use of literary features. (1) The anaphora of $כ$ at the beginning of verses 24 and 25 in the Hebrew text has not been rendered in Greek. (2) Moreover, the parallelism of verse $24 \mathrm{a}-\mathrm{b}$ was basically destroyed. Verse $24 \mathrm{~b}$ was rendered paraphrastically in Greek, anticipating $25 \mathrm{a}^{45}$ (3) The LXX, however, features an anadiplosis: $\phi o ́ \beta \omega$ at the end of verse 24 and $\phi \dot{\beta} \beta \circ$ at the very beginning of verse 25 . The anadiplosis could perhaps be a compensation for the elimination of the repetition of the root פ $25 \mathrm{a}$. (4) Additionally, verse 25 was rendered more parallel in the LXX. First, the Greek interprets פחדתי in 25a as an asyndetic relative clause, rendering it as a relative clause ôv

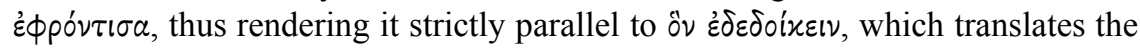
relative clause אשר יגרתי as a relative clause, the translator was able to eliminate the paratactical element of ויאתיני This way, the

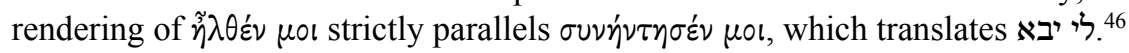

Though compensation for the loss of the repetition in the Hebrew text might be a "technique," I do not think one can distinguish for every case whether or not one can call a specific instance a matter of compensation.

\subsection{EXChANGing SyMmetry for CHIASMUS AND Vice Versa}

I have thus far shown that the occurrence of symmetrical word order in the Greek text can be due to the presence of a symmetry in the Hebrew text (see supra, for example $3: 1 ; 4: 7 ; 4: 9$ ). The use of a symmetrical pattern in the Greek text can, however, also go back to a chiasmus. We sometimes come across instances in which a chiasmus in the Hebrew has been eliminated and replaced by a symmetrical parallelism.

45. Dhorme, Job, 40.

46. See also supra on the order of verb and pronoun indicating the object. 
Job 3:6b

יבא אל ירחים במספר שנה בימי יחד אל

Let it not rejoice among the days of the year;

let it not come into the number of the months.

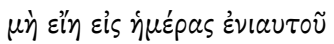

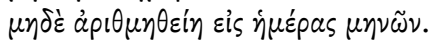

May it not exist among the days of the year

or be numbered among the days of the months.

Whereas the Hebrew has a clear chiastic structure, the Greek translation renders it as a symmetrical pattern. Moreover, where the Hebrew has במספר and, the translation reads í $\mu$ épas twice. The variation of the Hebrew text is eliminated, and the Greek introduces a repetition.

The same holds true for chiasmus. A chiasmus in Greek can have its basis in a chiasmus in the Hebrew (see supra, for example, $3: 12 ; 3: 14 ; 7: 14$ ) or occur in lines where the Hebrew is symmetrical.

Job 10:10

הלא כחלב תתיכני וכגבנה תקפיאני

Did you not pour me out like milk

and curdle me like cheese?

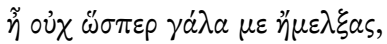

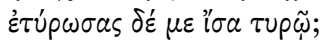

Did you not pour me out like milk

and curdle me like cheese?

With regard to the meaning of the verse, the Greek translation stays very close to the source text. It does, however, change the word order. The structure of the verse is chiastic, and some elements of variation are added. First, the position of the direct object expressed by the personal pronoun $\mu \varepsilon$ varies (see supra). Second, the way in which the secundum comparatum is represented also varies. In Hebrew we have twice an identical construction, וכגבנה and, whereas in

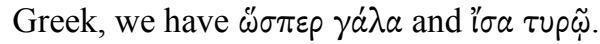

Job 5:20

ברעב פדך ממות ובמלחמה מידי חרב

In famine he will redeem you from death, and in war from the power of the sword.

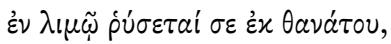

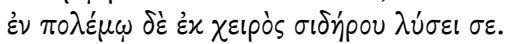
In famine he will rescue you from death, and in war he will free you from a blade's power. 
In Hebrew, we encounter a symmetrical structure, whereby the verb פדך is gapped. The translation seems to follow the Hebrew text quite closely. The lexical choices do not require additional explanation, and the word order is retained. The Greek text does, however, add $\lambda \dot{\sigma} \sigma \varepsilon l \sigma \varepsilon$ on the end of the verse, resulting in a partial chiasmus.

\section{CONCLUSION}

On the basis of the abovementioned examples, I present the following conclusions.

(1) The fact that we encounter some "literal" renderings might be an aspect of the so-called "easy technique." 47 Yet the Greek translation of Job has not been made on automatic pilot. The fact that we encounter stylistic features in the Greek text that seem to have no "identical" equivalent in the Hebrew points to sensitivities on behalf of the translator with regard to stylistic features.

(2) The stylistic context does not always dictate the rendering but can be a possible explanation in a number of instances. This illustrates that the particular sensitivities of the translator of Job towards stylistic features are interesting to study, since they provide us with insight in aspects of translational "freedom" of LXX Job.

(3) What motivates the translator to render or autonomously use a specific feature in a specific instance is difficult to say. For example:

- Formal patterns such $\mathrm{AB} / \mathrm{A}^{\prime} \mathrm{B}^{\prime}$ or $\mathrm{AB} / \mathrm{B}^{\prime} \mathrm{A}^{\prime}$ are sometimes rendered identically in Greek, in some instances even more "strictly" but also sometimes oppositely.

- Lexical repetition present in the Hebrew text is often avoided in the Greek, but not always. In addition, repetitions are sometimes added autonomously in the Greek translation, possibly but not necessarily as a compensation for losing a feature of the Hebrew in the process of translation.

The translator does not seem to be consistent at all. One can therefore only describe the different ways in which the LXX translator renders or autonomously uses features in the LXX and should refrain from saying anything about the translator's intentions.

(4) The examples I discussed above give rise to more questions. Why did the translator use these features autonomously, and what is their effect? Should we see "the literary" as their only function, or are they also performative or ideological? The LXX translation would as such also be an interesting topic to study from a more pragmatic or discourse-oriented approach.

47. See James Barr, The Typology of Literalism in Ancient Biblical Translations, MSU 15 (Göttingen: Vandenhoeck \& Ruprecht, 1979), 279-325, 300, which inspired Anneli Aejmelaeus, "Translation Technique and the Intention of the Translator," in Aejmelaeus, On the Trail of the of the Septuagint Translators, 59-70. 
(5) In any case, the use of literary features in the LXX provides us with a topic of research within the framework of the study of the translation technique of the LXX as a translation but can also be a new element in characterizing the LXX itself as a literary creation. 